\title{
Functional Heterogeneity within Rat Orbitofrontal Cortex in Reward Learning and Decision Making
}

\author{
(D)Alicia Izquierdo \\ Department of Psychology, Brain Research Institute, Integrative Center for Learning and Memory, and Integrative Center for Addictions, University of \\ California at Los Angeles, Los Angeles, California 90095
}

\begin{abstract}
Rat orbitofrontal cortex (OFC) is located in the dorsal bank of the rhinal sulcus, and is divided into the medial orbital area, ventral orbital area, ventrolateral orbital area, lateral orbital area, dorsolateral orbital area, and agranular insular areas. Over the past 20 years, there has been a marked increase in the number of publications focused on the functions of rat OFC. While collectively this extensive body of work has provided great insight into the functions of OFC, leading to theoretical and computational models of its functions, one issue that has emerged relates to what is defined as OFC because targeting of this region can be quite variable between studies of appetitive behavior, even within the same species. Also apparent is that there is an oversampling and undersampling of certain subregions of rat $\mathrm{OFC}$ for study, and this will be demonstrated here. The intent of the Viewpoint is to summarize studies in rat OFC, given the diversity of what groups refer to as "OFC," and to integrate these with the findings of recent anatomical studies. The primary aim is to help discern functions in reward learning and decision-making, clearing the course for future empirical work.
\end{abstract}

Key words: basolateral amygdala; cognitive flexibility; devaluation; OFC; prefrontal cortex; reversal learning

\section{Introduction}

Over the past 20 years, there has been a marked increase in the number of publications focused on the functions of the orbitofrontal cortex (OFC) (Fig. 1). While these studies have provided penetrating insight into the various functions of this region of the prefrontal cortex, one issue that has emerged relates to what is defined as OFC, as the specific cortical regions that have been studied are variable between experiments, even within the same species. The precipitous rise in the number of OFC reports in the past decade makes it even more necessary to carefully assess stereotaxic targeting in experimental studies for firm conclusions on appetitive, reward-related functions. Comparative studies of OFC function have yielded a long history of this brain region as a locus for inhibitory control, and there is convincing recent evidence of this as well (Torregrossa et al., 2008; Mansouri et al., 2014; Bryden and Roesch, 2015; Meyer and Bucci, 2016; Hardung et al., 2017). Yet this classic role for OFC (Gourley and Taylor, 2016) has become more nuanced with the findings of more recent studies of various other functions, positioning OFC as the locus of relative and economic value (Tremblay and Schultz, 1999; Padoa-Schioppa and Assad, 2006), expected or predicted outcomes (Tremblay and Schultz, 2000; Rudebeck and Murray,

\footnotetext{
Received July 4, 2017; revised Aug. 31, 2017; accepted Sept. 25, 2017.

This work was supported by University of California at Los Angeles Division of Life Sciences Recruitment and Retention fund, Opportunity fund, and Academic Senate Grant to A.I. I thank Alexandra Stolyarova and Evan Hart for conversations on the topic and help with figures; and Drs. Kate Wassum and Stan Floresco for helpful discussions and comments on an early version of this manuscript.

The author declares no competing financial interests.

Correspondence should be addressed to Dr. Alicia Izquierdo, University of California at Los Angeles, Department of Psychology, 1285 Franz Hall, Los Angeles, CA 90095-1563. E-mail: aizquie@psych.ucla.edu.

DOI:10.1523/JNEUROSCI.1678-17.2017

Copyright $\odot 2017$ the authors $\quad 0270-6474 / 17 / 3710529-12 \$ 15.00 / 0$
}

2014), confidence estimates (Kepecs et al., 2008), imagination and insight (Takahashi et al., 2013; Lucantonio et al., 2014, 2015), Bayesian belief (Jang et al., 2015), cognitive map of task space (Wilson et al., 2014), state space (Schuck et al., 2016; Nogueira et al., 2017), regret (Camille et al., 2004; Steiner and Redish, 2014), and credit assignment (Walton et al., 2011; Chau et al., 2015; Akaishi et al., 2016; Noonan et al., 2017). Given many highquality and in-depth analyses on what the OFC does and does not do (Noonan et al., 2012; Rudebeck and Murray, 2014; Stalnaker et al., 2015), there appears to be no shortage of theoretical viewpoints on the subject.

A review of OFC function across species (Wallis, 2011) revealed that studies of monkey OFC function have primarily focused on anterior rather than posterior $\mathrm{OFC}$, and that rat studies have instead emphasized lateral over medial OFC. Indeed, many reports of OFC function do not specify the subregion within OFC that is the focus of the work, an important detail that is sometimes buried in the methods. Also apparent is that there is an oversampling of certain subregions of rat OFC for study, and this will be demonstrated here. The primary intent of the present Viewpoint is to summarize recent targeting in rat OFC (given the diversity in coordinates used) and, secondarily, to integrate these with the findings of recent anatomical studies. Collectively, the goal is to help clear the course for future empirical work.

\section{What is rat $\mathrm{OFC}$ ?}

Rat OFC is located in the dorsal bank of the rhinal sulcus, and is divided into the medial orbital area (MO), ventral orbital area (VO), ventrolateral orbital area (VLO), lateral orbital area (LO), dorsolateral orbital area (DLO), and agranular insular (AI) areas (Ray and Price, 1992; Ongür and Price, 2000; Rempel-Clower, 2007). Although all prefrontal regions are agranular in the rat 


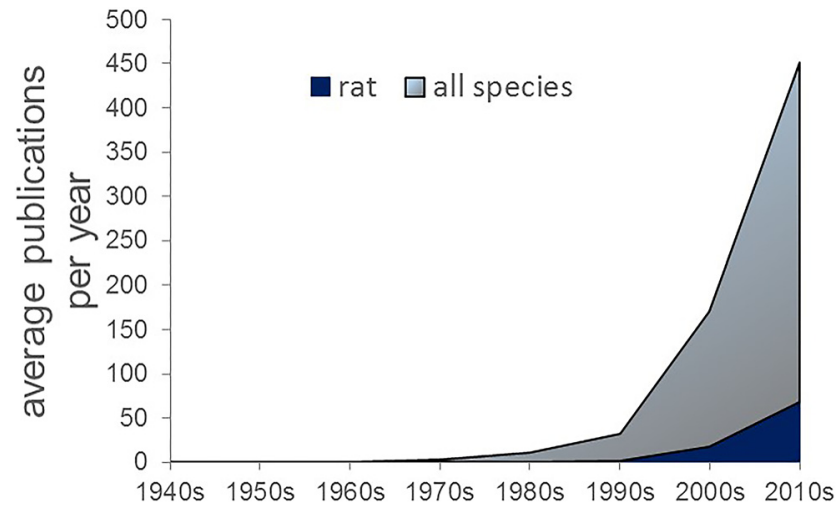

Figure 1. Number of reports on $\mathrm{OFC}$ in all species. PubMed search terms "OFC," "Orbitofrontal Cortex," and "Orbital Prefrontal Cortex" from 1948 to 2014. The steepest rise in the number of publications occurred in the early 2000 s, which was preceded by a more gradual increase in the 1990s. Rat studies, although increasing in number over the past decade, still account for a minority of reports on $\mathrm{OFC}$.

brain, these sectors of rat OFC are thought to be homologous to approximately one-third of monkey caudal orbitomedial prefrontal cortex because these regions share similar positioning and connectivity to subcortical structures (Price, 2007). In particular, mediodorsal thalamus is reciprocally connected to all parts of OFC in both rats and monkeys (Rose and Woolsey, 1948; Groenewegen, 1988; Uylings and van Eden, 1990; Ray and Price, 1992; Ongür and Price, 2000; compare Markowitsch and Pritzel, 1979). Additional criteria have since been included to designate the "parts" of prefrontal cortex across species: namely, by outlining behavioral, neurochemical, and electrophysiological properties (Markowitsch and Pritzel, 1979), and by studying phylogenetic (Passingham and Wise, 2012) and ontogenetic relationships (Goldman, 1971) of these areas.

A recent comprehensive comparative analysis of collections of monkey and rat anatomical tracing experiments enable us to make "connectivity-based inferences about homologies" across these species (Heilbronner et al., 2016). Specifically, there is similar OFC-striatal organization across rat and monkey, with comparable efferent hubs: MO in rat and medial OFC in monkey projecting to ventromedial segments of striatum, and LO in rat and central-lateral OFC in monkey projecting to central and lateral segments of striatum in both species. Interestingly, primarily on the basis of their striatal terminal fields, Heilbronner et al. (2016) clustered rat VO and LO more closely together than VO and $\mathrm{MO}$, and equated rat VO and LO (and this likely extends to VLO) as collectively homologous to monkey central-lateral OFC.

Hoover and Vertes (2011) came to slightly different conclusions for rat $\mathrm{MO}$ and $\mathrm{VO}$ following a study of brain-wide projections from these OFC sectors. They found that rat VO and MO send high density fibers to the same cortical areas ( $\mathrm{MO}$ to $\mathrm{VO}, \mathrm{VO}$ to $\mathrm{MO}$, and both $\mathrm{MO}$ and $\mathrm{VO}$ to anterior cingulate, prelimbic, and infralimbic), caudate-putamen, mediodorsal thalamus, lateral hypothalamus, most areas of the hippocampus, substantia nigra, and ventral tegmental area. However, there are surprising and notable differences as well: MO projects densely to basolateral and central amygdala, whereas $\mathrm{VO}$ projects less so, and $\mathrm{MO}$ projects more densely to nucleus accumbens than VO. In general, MO sends fibers more broadly throughout limbic areas than does VO. Interestingly, both MO and VO do not project densely to LO. On this basis, Hoover and Vertes (2011) proposed instead that $\mathrm{MO}$ and VO have an important shared role in the affective and cognitive integration of goal-directed behavior. As for the dis-

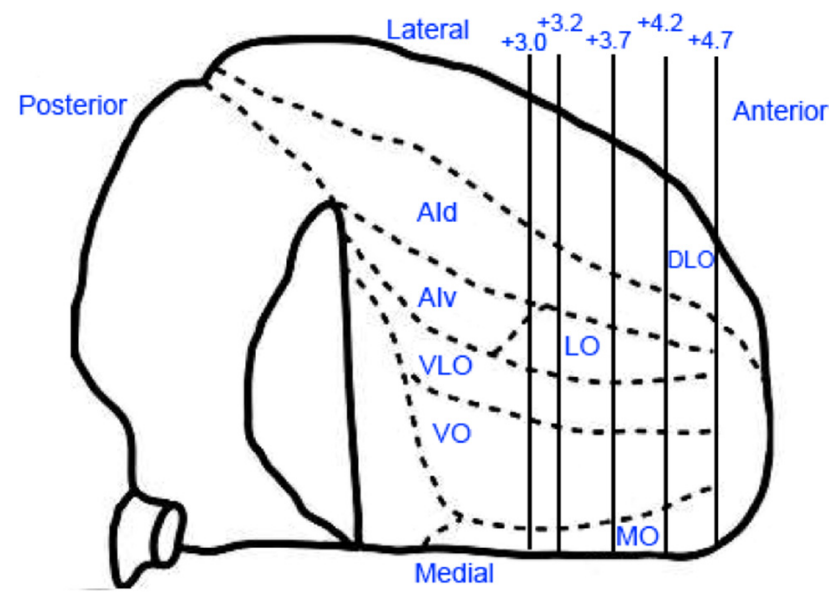

Figure 2. Parcellation of rat OFC as determined by anatomical tracing studies. Rat OFC is depicted in this ventral view of the right hemisphere. Adapted with permission from RempelClower (2007). Rat OFC is divided in the M0, V0, VLO, LO, DLO, and Al areas. Numerals on upper right indicate the anterior (right)/posterior (left) distance (in millimeters) from bregma (Paxinos and Watson, 2007).

tinctions between rat VLO, LO, DLO, and AI (as labeled in the atlas by Paxinos and Watson, 2007), there are no brain-wide systematic tracer studies of projections arising from these specific sectors like that conducted by Hoover and Vertes (2011) for MO and VO, but we can rely on earlier anatomical work (Price, 2007; Rempel-Clower, 2007) and behavioral distinctions. The similarity in the functional (behavioral) data I present here supports the view that MO and VO may constitute a functional unit or "network" (Price, 2007) in reward learning and decision making. Additionally, consistent with recent anatomical studies (Hoover and Vertes, 2011; Heilbronner et al., 2016), as one moves medially to laterally in rat OFC, there is less involvement of systems linked to affective and motivational states and more involvement of systems supporting sensory integration (i.e., in the associations of stimuli/cues and sensory events to outcomes). This will also be reflected in the functional evidence I review here.

In the following sections, I outline evidence for clusters of function in rat OFC, based in part on a study of stereotaxic coordinates used across reports, and considering recent anatomy papers of rat OFC (Hoover and Vertes, 2011; Heilbronner et al., 2016). Included in this analysis are behavioral studies partnered with a variety of approaches: excitotoxic lesions, electrophysiological recordings, pharmacological inactivations, as well as chemogenetic and optogenetic techniques to target cell populations within rat OFC. As will be noted, chemogenetic and optogenetic targeting of rat OFC is, as yet, quite scarce relative to work using older technologies. In general, the pattern of functional heterogeneity within rat OFC summarized here lends credence to the idea proposed a decade ago by Rempel-Clower (2007), that special attention be paid to the medial-lateral organization of rat OFC (Fig. 2), as this dimension has the most correspondence to the rostral-caudal organization of monkey OFC in goal-directed behavior (Price, 2007).

I include in this Viewpoint only studies focused on appetitive behavior, specifically investigations of food reward learning and decision-making. Here I also focus on discerning functions in rat OFC, exclusively, although it should be mentioned that there are numerous noteworthy investigations on the involvement of mouse OFC in reinforcement processes (Bissonette et al., 2008, 2015; Brigman et al., 2013; Burguière et al., 2013; Gourley et al., 2013, 2016; Gremel and Costa, 2013; Bakhurin et al., 2017; Radke 
Table 1. Targeting of rat MO, VO, LO, DLO frontal cortex and Al cortex ${ }^{a}$

\begin{tabular}{|c|c|c|c|c|c|}
\hline Reference & Sex and strain & OFC target & Method & Behavioral task & Finding \\
\hline Chudasama and Robbins, 2003 & Male, Lister Hooded & $\mathrm{MO}+\mathrm{VO}+\mathrm{LO}+\mathrm{DLO}+\mathrm{Al}$ & Quinolinic acid lesions & $\begin{array}{l}\text { Visual discrimination and reversal } \\
\text { learning }\end{array}$ & $\begin{array}{l}\text { Impaired Pavlovian autoshaping and } \\
\text { increased perseveration in reversal } \\
\text { learning }\end{array}$ \\
\hline Chudasama et al., 2003 & Male, Lister Hooded & $\mathrm{MO}+\mathrm{VO}+\mathrm{LO}+\mathrm{DLO}+\mathrm{Al}$ & Quinolinic acid lesions & 5-choice serial reaction time & $\begin{array}{l}\text { Perseveration when the intertrial } \\
\text { interval was long and unpredictable }\end{array}$ \\
\hline Winstanley et al., 2004 & Male, Lister Hooded & $\mathrm{MO}+\mathrm{VO}+\mathrm{LO}+\mathrm{DLO}+\mathrm{Al}$ & Quinolinic acid lesions & Delay discounting & $\begin{array}{l}\text { Increased preference for larger, delayed } \\
\text { rewards }\end{array}$ \\
\hline Rudebeck et al., 2006 & Male, Lister Hooded & $\mathrm{MO}+\mathrm{VO}+\mathrm{LO}+\mathrm{DLO}+\mathrm{Al}$ & Quinolinic acid lesions & Cost-benefit decision making & $\begin{array}{l}\text { Intact effort-based choices, increased } \\
\text { impulsive choices }\end{array}$ \\
\hline Rudebeck et al., 2007 & Male, Lister Hooded & $\mathrm{MO}+\mathrm{VO}+\mathrm{LO}+\mathrm{DLO}+\mathrm{Al}$ & Quinolinic acid lesions & Emotional and social behavior & $\begin{array}{l}\text { Heightened responses in fear context, } \\
\text { increased aggression, correlated } \\
\text { with impulsivity }\end{array}$ \\
\hline Boulougouris et al., $2007^{b}$ & Male, Lister Hooded & $\mathrm{MO}+\mathrm{VO}+\mathrm{LO}+\mathrm{DLO}+\mathrm{Al}$ & Quinolinic acid lesions & Spatial reversal learning & $\begin{array}{l}\text { Early phase impairment with } \\
\text { perseveration }\end{array}$ \\
\hline Eagle et al., 2008 & Male, Lister Hooded & $\mathrm{MO}+\mathrm{VO}+\mathrm{LO}+\mathrm{DLO}+\mathrm{Al}$ & Quinolinic acid lesions & Stop signal task & Slower reaction times to stop signal \\
\hline Ostrander et al., 2011 & Male, Long Evans & $\mathrm{MO}+\mathrm{VO}+\mathrm{LO}+\mathrm{DLO}+\mathrm{Al}$ & Ibotenic acid lesions & Effort-based decision making & $\begin{array}{l}\text { Intact effort discounting, impaired } \\
\text { cue-guided effort choices }\end{array}$ \\
\hline Izquierdo et al., 2013 & Male, Long Evans & $\mathrm{MO}+\mathrm{VO}+\mathrm{LO}+\mathrm{DLO}+\mathrm{Al}$ & Ibotenic acid lesions & $\begin{array}{l}\text { Visual discrimination and reversal } \\
\text { learning }\end{array}$ & $\begin{array}{l}\text { Intact discrimination learning, } \\
\text { impaired reversal learning }\end{array}$ \\
\hline Mar et al., 2011 & Male, Lister Hooded & $\mathrm{MO}+\mathrm{VO}+\mathrm{LO}+\mathrm{DLO}+\mathrm{Al}$ & NMDA lesions & Delay discounting & $\begin{array}{l}\text { Transient delay aversion, recovered } \\
\text { with training }\end{array}$ \\
\hline
\end{tabular}

${ }^{a}$ Stereotaxic coordinates for M0 + V0 + LO + DLO + Al: Site 1, APf 4.0, ML \pm 0.8, DV - 3.4; Site 2, AP 3.7, ML \pm 2.0, DV - 3.6; Site 3, AP 3.2, ML \pm 2.6, DV - 4.4.

${ }^{b}$ This group had the most anterior site at 4.7 .

et al., 2017), and associated reviews highlighting contributions of distinct rodent frontocortical subregions to reward-related behavior (Jentsch et al., 2014; Hamilton and Brigman, 2015). One limitation of studying stereotaxic targeting in any species is that the coordinates alone are of limited use without parallel review of the unintended damage or additional spread of infusion that typically occurs with lesions or pharmacological manipulations, respectively. These are typically found in the representative photomicrographs and reconstructions within each report, and can also be gauged from infusion volumes. All of these factors have been considered here and are part of the evaluation in each section below. Finally, I summarize lesion effects together with temporary inactivation effects, although it is known that recovery of function has been demonstrated after cortical lesions where behavioral effects resolve spontaneously, perhaps due to adaptations or "repurposing" of other interconnected cortical regions (Otchy et al., 2015). Such a consideration is indeed a limitation for direct comparison of lesions with transient inactivations. Experimental design is evaluated even more carefully in these cases, to better ascertain the possibility of recovery or transient effects. Standard conventions apply when referring to stereotaxic coordinates: anteroposterior (AP), mediolateral (ML), dorsoventral (DV), with reference to distance in millimeters from bregma according to Paxinos and Watson (2007).

\section{Multiple OFC regions ( $\mathrm{MO}+\mathrm{VO}+\mathrm{LO}+\mathrm{DLO}+\mathrm{AI})$}

The largest area targeted in rat $\mathrm{OFC}$, by volume, includes very anterior portions of $\mathrm{MO}$ and $\mathrm{VO}$ frontal cortex (AP 4.0; ML \pm 0.8 , one group had the most anterior target of 4.7) (Boulougouris et al., 2007), VO and VLO (at AP 3.7, and ML within \pm 2.0 ), and more posterior VLO (at AP 3.2, and ML \pm 2.6 ) (Chudasama and Robbins, 2003; Rudebeck et al., 2006, 2007; Ostrander et al., 2011; Izquierdo et al., 2013). Many of the studies using these coordinates are summarized in Table 1. Only a handful of investigations reported effects following administration of NMDA or ibotenic acid microinfusions (Mar et al., 2011; Ostrander et al., 2011; Izquierdo et al., 2013), whereas most groups delivered quinolinic acid. Although quinolinic acid acts as an agonist at NMDA receptors, specifically NR2A and NR2B (de Carvalho et al., 1996), its excitotoxicity has been linked to other mechanisms beyond activity at the presynaptic receptor, including oxidative stress, inflammation, and mitochondrial dysfunction (Lugo-Huitrón et al., 2013). As such, administration of quinolinic acid may result in longer-lasting, more potent lesion effects.

As might be expected from the coordinates, the studies beginning in the early 2000s listed in Table 1 generally report broad effects on reward-related behaviors. Additionally, behavior across these studies was assessed only in male rats and in two predominant strains, Long-Evans or Lister Hooded. Importantly, although the stereotaxic coordinates were used to target MO, VO, and VLO, visual inspection of reconstructions and representative photomicrographs in these studies demonstrates that LO, DLO, and ventral AI areas also constituted part of the lesions. In the first demonstration of the functional heterogeneity of rat frontal cortex, Chudasama and Robbins (2003) showed that large lesions of OFC resulted in impaired approach to the conditioned stimulus associated with reward $\left(\mathrm{CS}^{+}\right)$and increased perseveration in reversal learning, defined as repeated errors according to past rules of reinforcement. This was in line with an older literature of large lesions of OFC in monkeys resulting in behavioral inflexibility, a hallmark feature of OFC damage or dysfunction (Butter et al., 1963; Jones and Mishkin, 1972; Kolb, 1984). Many subsequent studies in rats using $\mathrm{MO}+\mathrm{VO}+\mathrm{LO}+\mathrm{DLO}+\mathrm{AI}$ coordinates corroborate a behavioral rigidity effect across paradigms ranging from the stop signal reaction time task (Eagle et al., 2008), 5-choice serial reaction time task (Chudasama et al., 2003), leftright lever (spatial) reversals (Boulougouris et al., 2007), and reversal of reward contingencies associated with visual stimuli presented on touchscreens (Chudasama and Robbins, 2003; Izquierdo et al., 2013). Although our group found that OFClesioned rats required a greater number of sessions to reach criterion for the reversal phase compared with sham-operated controls (Izquierdo et al., 2013), we found no evidence of in- 


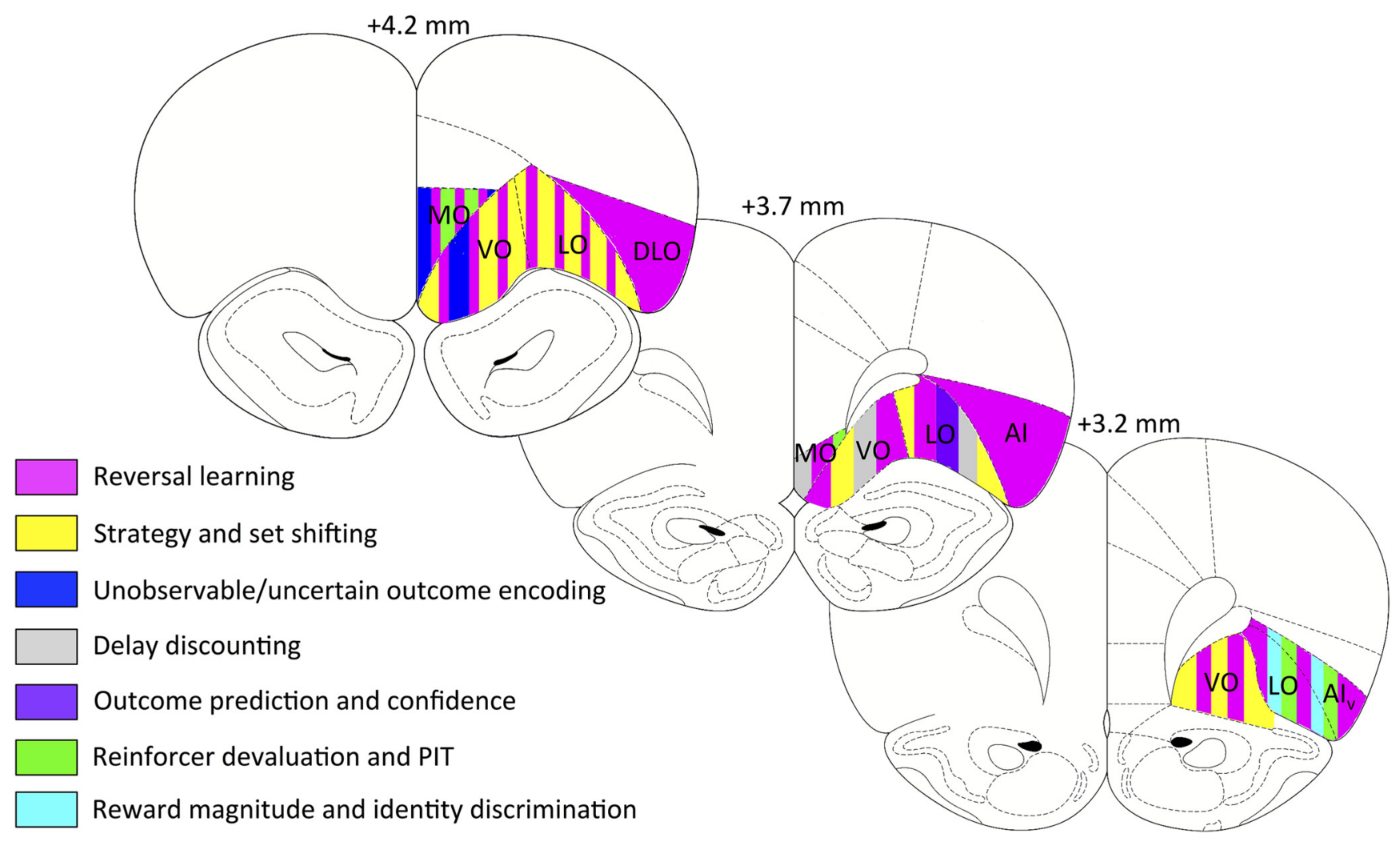

Figure 3. Coronal sections depicting functional heterogeneity within rat OFC. Behavioral task effects are mapped onto coronal sections of rat OFC. Numerals on top of each section indicate the AP distance (in millimeters) from bregma (Paxinos and Watson, 2007).

creased perseveration as reported by others (Chudasama and Robbins, 2003; Chudasama et al., 2003; Boulougouris et al., 2007). Because lesion placements were identical, and given that experimental design and timeline were similar across these studies, it may be that ibotenic acid lesions produced more subtle effects than quinolinic acid lesions, as described above.

These large lesions also produced effects on cost-benefit decision-making, specifically on delay-based tasks. In some cases, groups reported increased choice of smaller-sooner rewards over larger-later rewards (Rudebeck et al., 2006, 2007; Mar et al., 2011) indicating impulsive decision making, yet others found the opposite effect (Winstanley et al., 2004). Later studies clarified a role for OFC following a more specific inactivation of $\mathrm{LO}$ in choices involving delay costs (Zeeb et al., 2010): LO inactivations produce impulsive choice when cues are present versus a delay tolerance (or willingness to wait) when cues are absent. One approach to pinpoint OFC function is to assay a comparison behavior in the same animals or within the same experiment, using the same coordinates for OFC. As examples, conclusions can be drawn when investigators report both spared and impaired functions within the same study: Rudebeck et al. (2006) and Ostrander et al. (2011) both showed that rats exhibited intact effort discounting following OFC lesions (e.g., the effort requirement did not produce a steeper discounting for a larger reward relative to controls), but OFC-lesioned rats did show impairments on delay- and cueguided appetitive behavior, respectively. In summary, the studies involving this broad targeting of OFC in rats reveal involvement in the following: delay, not effort discounting (e.g., selective modulation of impulsive choice via wait time); deterministic (fully predictive) reversal learning, not initial discrimination learning (Izquierdo et al., 2017); and in cue-guided choices involving cost-benefit evaluation. Notably, there is no published evidence of probabilistic reversal learning assessment using these coordinates in rats. The task effects are mapped onto coronal sections of rat OFC (Fig. 3).

Other groups have administered similarly large lesions in rats but included much more lateral portions of OFC ( $>1 \mathrm{~mm}$ lateral to those described above) to include neurons in VLO, LO, and both ventral AI cortex (Pickens et al., 2003, 2005). Those effects will be described separately in subsequent sections.

\section{MO}

Few investigations of rat OFC have selectively probed MO function (Table 2). Located at the most anterior portion of OFC (AP between 4.4 to 4.0 ) and with ML between \pm 0.5 and \pm 1.6 , it is perhaps the most difficult to target from a flat skull surface due to the overlying midsagittal sinus, causing some to use an angled approach (Lopatina et al., 2016). There is diversity in findings from lesions and inactivations of MO. In contrast to results following large OFC lesions, one group reported an increased preference for large delayed rewards following NMDA lesions of MO (Mar et al., 2011) and another found intact delay discounting but increased choice of a risky option following inactivation of $\mathrm{MO}$ (Stopper et al., 2014). Again, it is difficult to compare lesion and inactivation methods directly, however, the task methods in these two studies were similar, except for the amount of training received: choice of larger, delayed reward occurred after extensive experience with the task in Mar et al. (2011), but MO-lesioned rats were indistinguishable from controls in early phases of the task, consistent with Stopper et al. (2014). Together, the findings support the idea that MO may be important in updating value (and consequently a costbenefit ratio) over time.

There is better agreement on the role of MO in value, in conditions of uncertainty. Two groups (Burton et al., 2014; Lopatina 
Table 2. Targeting of rat MO frontal cortex ${ }^{a}$

\begin{tabular}{|c|c|c|c|c|c|}
\hline Reference & Sex and strain & $\begin{array}{l}\text { OFC } \\
\text { target }\end{array}$ & Method & Behavioral task & Finding \\
\hline Fuchs et al., 2004 & Male, Sprague Dawley & MO & $\begin{array}{l}\text { NMDA lesions or baclofen/muscimol } \\
\text { microinfusions }\end{array}$ & $\begin{array}{l}\text { Cue-induced and drug-primed reinstatement } \\
\text { of cocaine self-administration }\end{array}$ & $\begin{array}{l}\text { Intact cue-induced reinstatement; attenuated } \\
\text { drug-primed reinstatement }\end{array}$ \\
\hline Mar et al., 2011 & Male, Lister Hooded & M0 & NMDA lesions & Delay discounting & $\begin{array}{l}\text { Increased preference for large delayed rewards; } \\
\text { improved reversal learning }\end{array}$ \\
\hline Stopper et al., 2014 & Male, Long Evans & MO & Baclofen/muscimol microinfusions & $\begin{array}{l}\text { Probabilistic discounting and delay } \\
\text { discounting }\end{array}$ & $\begin{array}{l}\text { Intact delay discounting; increased choice of risky } \\
\text { option }\end{array}$ \\
\hline Burton et al., 2014 & Male, Long Evans & MO & Electrophysiological recording & $\begin{array}{l}\text { Choice between different reward magnitude } \\
\text { and delays }\end{array}$ & $\begin{array}{l}\text { Neurons signal cues predicting lower value } \\
\text { outcomes }\end{array}$ \\
\hline Bradfield et al., 2015 & Male, Long Evans & MO & $\begin{array}{l}\text { NMDA lesions and inhibitory } \\
\text { DREADDs }\end{array}$ & $\begin{array}{l}\text { Action selection of observable and } \\
\text { unobservable outcomes }\end{array}$ & $\begin{array}{l}\text { Reliance on the value of only observable } \\
\text { outcomes }\end{array}$ \\
\hline Dalton et al., 2016 & Male, Long Evans & MO & Baclofen/muscimol microinfusions & $\begin{array}{l}\text { Probabilistic discrimination and reversal } \\
\text { learning }\end{array}$ & $\begin{array}{l}\text { Impaired probabilistic discrimination learning, } \\
\text { increased perseveration, and reduced sensitiv- } \\
\text { ity to positive and negative feedback }\end{array}$ \\
\hline Lopatina et al., 2016 & Male, Long Evans & MO & Electrophysiological recording & Odor-based unblocking & $\begin{array}{l}\text { Neurons acquired responses to cues predicting } \\
\text { decreases in reward value }\end{array}$ \\
\hline Lopatina et al., 2017 & Male, Long Evans & MO & Electrophysiological recording & $\begin{array}{l}\text { Behavioral states in and across cue-outcome } \\
\text { trials }\end{array}$ & Neurons track different value trial types \\
\hline
\end{tabular}

${ }^{a}$ Stereotaxic coordinates for M0: AP 4.4, ML $\pm 0.7, \mathrm{DV}-3.2$ from dura (Stopper et al., 2014); AP 4.2, ML $\pm 0.6, \mathrm{DV}-4.3$ (Fuchs et al., 2004); AP 4.2, ML $\pm 0.7, \mathrm{DV}-3.2$ from dura (Dalton et al., 2016); AP 4.0, ML $\pm 0.5, \mathrm{DV}-4.1$ (Bradfield et al., 2015); single-unit recordings at coordinates approached at a $13^{\circ}$ angle, AP 4.4, ML $\pm 1.58, \mathrm{DV}-2.78$ from brain surface (Lopatina et al., 2016, 2017).

et al., 2016), using different behavioral paradigms, found that neurons in $\mathrm{MO}$ acquire responses to cues predicting decreases, not increases, in reward value. Bradfield et al. (2015) administered MO lesions or inhibition of MO via Designer Receptors Exclusively Activated by Designer Drugs (DREADDs) and tested rats on action selection involving observable and unobservable outcomes (food rewards, in this case). This group found that taking MO "offline" selectively impaired rats' performance in the unobservable condition. There was also an impairment in responses to instrumental outcome devaluation. Importantly, rats were not impaired if they had access to the outcomes during test, generally supporting the idea that MO is required for maintaining a representation of outcomes when the outcomes are not available. Consistent with the proposal that MO supports behavior in uncertain situations, Dalton et al. (2016) found that inactivation of MO in well-trained rats resulted in impaired probabilistic discrimination and reversal learning, more perseverative errors, and fewer reversals completed per session. One possible explanation is that inactivating $\mathrm{MO}$ could render rats more stimulusdependent (i.e., more reliant on observable stimuli and their outcomes). Overall, the available evidence suggests that MO has an important role in risk and probability discounting, and in supporting value choices when outcomes are either ambiguous or changing in value. One way in which MO may support all these functions is by contributing a representation (e.g., memory) of reward value for use in guiding actions. This may be achieved by stable neuronal ensemble activity in this region (Lopatina et al., 2017).

Is value representation a specialized function of $\mathrm{MO}$ or is it part and parcel of a broader OFC function? This remains to be fully uncovered given the relatively few studies on MO to date. The fact that $\mathrm{MO}$ and $\mathrm{VO}$ share robust corticocortical connectivity (Hoover and Vertes, 2011) helps us predict, however, that MO and VO will share more complementary functions in support of value learning compared with more lateral sectors.

\section{VO and VLO}

Few groups have selectively targeted VO (reviewed below). Of all sectors of OFC, VO and VLO are supported by the most mixed evidence. Here, the distinction drawn between VLO versus LO was primarily for the purpose of simplifying comparisons and was determined on the basis of ML extent: VLO constituted coordinates that extended no more than \pm 2.5 from the midline, at any AP level through OFC (between 4.2 and 3.3; Table 3). Mobini et al. (2002) and Kheramin et al. (2002, 2003, 2005) administered quinolinic acid lesions that also included VO regions predominantly, but with additional intrusion into MO. These investigators tested rats on delay and probability tasks and found that VLO-lesioned rats preferred smaller-sooner rewards (i.e., a delayaverse phenotype) and more certain rewards (i.e., risk-aversion). This is consistent with the effects of large OFC lesions but inconsistent with $\mathrm{MO}$ lesions or inactivations that produce no effect or even improvements over time. This suggests it is VLO (not MO) that supports value over increasing delays, contributing to normal delay discounting performance.

VLO has also been the focus of neurophysiological recording studies by several different groups (Young and Shapiro, 2011; Steiner and Redish, 2012, 2014; Riceberg and Shapiro, 2017). In general, there is converging evidence that neurons in VLO signal an expected outcome (Steiner and Redish, 2012), a missed outcome (Steiner and Redish, 2014), and that neuronal firing in VLO is engaged when stimulus-outcome contingencies become stable with experience (Riceberg and Shapiro, 2012, 2017). This is a difference with $\mathrm{MO}$, where changes are a more important feature than stability. A mechanism for this "stabilizing" feature in VLO is yet to be determined, but one possibility is that it involves formation of a learning set (described by Izquierdo et al., 2017). For example, Brown and colleagues reported evidence that OFC (in particular, VLO) is important for the acquisition of attention sets and overcoming nonreward in reversal learning (McAlonan and Brown, 2003; Tait and Brown, 2007; Chase et al., 2012). Lesions of VLO render the animal in need of more evidence to adjust behavior (i.e., more trials to shift) (Chase et al., 2012), which authors explain as a failure in linking relevant cues to unexpected outcomes but could also be attributed to an impaired ability to stabilize stimulus-outcome contingencies over time.

An interesting recent finding (Meyer and Bucci, 2016) probing the role of VLO made use of a "negative occasion setting" paradigm, a behavioral task that requires the rat to monitor the context in which it needs to act or withhold response. Using an 
Table 3. Targeting of rat VO and VLO frontal cortex ${ }^{a}$

\begin{tabular}{|c|c|c|c|c|c|}
\hline Reference & Sex and strain & $\begin{array}{l}\text { OFC } \\
\text { target }\end{array}$ & Method & Behavioral task & Finding \\
\hline $\begin{array}{l}\text { Mobini et al., 2002; } \\
\text { Kheramin et al., 2002, } \\
\text { 2003, } 2005\end{array}$ & Female, Wistar & $\begin{array}{l}\text { VO }+ \\
\text { LO }\end{array}$ & Quinolinic acid lesions & $\begin{array}{l}\text { Delayed and probabilistic reinforcement; } \\
\text { intertemporal choice }\end{array}$ & $\begin{array}{l}\text { Preference for small immediate, certain } \\
\text { rewards; increased sensitivity to ratio of } \\
\text { option magnitude differences }\end{array}$ \\
\hline Young and Shapiro, 2011 & Male, Long Evans & VLO & $\begin{array}{l}\text { Electrophysiological } \\
\text { recording }\end{array}$ & $\begin{array}{l}\text { Spatial reversals and strategy switches in } \\
\text { a plus maze }\end{array}$ & $\begin{array}{l}\text { Firing distinguished rewarded paths and } \\
\text { correlated with performance as rats learned } \\
\text { newly rewarded outcomes }\end{array}$ \\
\hline $\begin{array}{l}\text { Steiner and Redish, 2012, } \\
2014\end{array}$ & Male, Fisher Brown Norway & VLO & $\begin{array}{l}\text { Electrophysiological } \\
\text { recording }\end{array}$ & Continuous loop multiple choice maze & $\begin{array}{l}\text { Firing signals expected outcomes; firing signals } \\
\text { a "missed" option }\end{array}$ \\
\hline $\begin{array}{l}\text { McAlonan and Brown, 2003; } \\
\text { Tait and Brown, 2007; } \\
\text { Chase et al., } 2012\end{array}$ & Male, Lister Hooded & VLO & Ibotenic acid lesions & $\begin{array}{l}\text { Attentional set formation and shifts and } \\
\text { reversal learning }\end{array}$ & $\begin{array}{l}\text { Slower to acquire attention set, more trials to } \\
\text { shift, and impaired reversal learning }\end{array}$ \\
\hline Meyer and Bucci, 2016 & Male, Long Evans & VLO & Inhibitory DREADDs & Negative occasion setting & Underactivity decreases inhibitory learning \\
\hline $\begin{array}{l}\text { Jean-Richard-Dit-Bressel } \\
\text { and McNally, } 2016\end{array}$ & Male, Sprague Dawley & VLO & $\begin{array}{l}\text { Baclofen/muscimol } \\
\text { microinfusion }\end{array}$ & $\begin{array}{l}\text { Aversive instrumental learning and } \\
\text { decision making }\end{array}$ & Impaired use of aversive instrumental memory \\
\hline Riceberg and Shapiro, 2017 & Male, Long Evans & VLO & $\begin{array}{l}\text { Electrophysiological } \\
\text { recording }\end{array}$ & $\begin{array}{l}\text { Spatial learning in a plus maze that } \\
\text { varied frequency of reversal }\end{array}$ & $\begin{array}{l}\text { Firing signals past, present, and pending } \\
\text { events when contingencies are stable }\end{array}$ \\
\hline $\begin{array}{l}\text { Stolyarova and Izquierdo, } \\
2017\end{array}$ & Male, Long Evans & V0 & NMDA lesions & $\begin{array}{l}\text { Learning value distributions and } \\
\text { adjusting to changes in those } \\
\text { distributions }\end{array}$ & $\begin{array}{l}\text { Failure to represent the full delay distribution } \\
\text { and inability to adjust to better than } \\
\text { expected outcomes }\end{array}$ \\
\hline Hardung et al., 2017 & Male, Sprague Dawley & V0 & $\begin{array}{l}\text { Optogenetic inhibition and } \\
\text { electrophysiological } \\
\text { recording }\end{array}$ & Stop signal task & Slower reaction times to stop signal \\
\hline
\end{tabular}

${ }^{a}$ Stereotaxic coordinates for V0 + L0: Site 1, AP 3.7, ML $\pm 1.2, \mathrm{DV}-4.8 ;$ Site 2, AP 3.7, ML $\pm 2.8, \mathrm{DV}-4.4$. Stereotaxic coordinates for VL0: tetrode recordings at AP 4.0, ML $\pm 2.4, \mathrm{DV}-3.0$ to -3.5 (Young and Shapiro, 2011), and similar coordinates for tetrode recordings at AP 3.5, ML \pm 2.5 (Steiner and Redish, 2012, 2014). Lesion coordinates: AP 4.0, ML \pm 2.0, DV -4.5 , from skull surface (McAlonan and Brown, 2003; Tait and Brown, 2007; Chase et al., 2012). Expression of DREADDs reporter: Site 1, AP 4.5, ML $\pm 0.5, \mathrm{DV}-4.9$; Site 2, AP 4.2, ML $\pm 2.2, \mathrm{DV}-4.8$; Site 3, AP 3.3, ML $\pm 2.2, \mathrm{DV}-5.6$ (Meyer and Bucci, 2016). Guide cannulae implanted at a 10 angle at AP 4.5, ML \pm 1.7, DV -3.9 (Jean-Richard-Dit-Bressel and McNally, 2016). Stereotaxic coordinates for V0: one group selectively targeted V0 (separately from M0 and L0), AP 3.24, ML \pm 2.0 , DV -4.4 (Hardung et al., 2017). Our laboratory targeted V0, but with additional intrusion in M0: AP 3.7; ML \pm 2.0 ; DV -4.6 (Stolyarova and Izquierdo, 2017).

inhibitory DREADDs approach, Meyer and Bucci (2016) found that inhibiting VLO function disrupts the ability to discriminate the context in which to act (i.e., withhold response). Similarly, another group (Jean-Richard-Dit-Bressel and McNally, 2016) trained rats to earn food rewards on two levers presented individually. One of the levers delivered mild punishment, the other, only reward. VLO inactivation did not impair initial learning (rats decreased their responses to punished lever) but did increase responding to the punished lever once stimulus-outcome associations had already been well established. It is still unclear how VLO supports such flexible responding. Supporting an earlier result by Eagle et al. (2008), Hardung et al. (2017) found that selective optogenetic inhibition of VO impaired inhibitory control on the stop signal reaction time task, which authors describe as a lack of "reactive movement control." Indeed, this finding is consistent with the behavioral rigidity or enhanced perseveration resulting from large lesions of OFC, yet also consistent with the idea that VLO supports either the "occasion" on which to act, or the remapping of relevant cues to outcomes, as described above.

Our laboratory has a recent finding (Stolyarova and Izquierdo, 2017) demonstrating that VO may be particularly important in learning about value under conditions of delay uncertainty. In our task, rats were required to select between two visual stimuli associated with different delay distributions to reward. The stimuli were associated with the same mean wait times to reward and imposed the same reward rate over the session, only the variance of the delays differed. One stimulus was associated with a highly variable wait time and another with a relatively stable wait time. Unlike control animals, rats with NMDA lesions of VO visited the food magazine closest to the average time when reward was expected, failing to represent the more extreme instances of the highly variable distribution (i.e., shortest and longest wait times possible). Lacking access to a representation of the richness of the outcome distribution, VO rats over-rely on the average cached value. We interpret these findings as providing additional evidence that this sector of OFC may be involved in more than motor inhibition but rather that it exerts a more complex function in value learning when outcomes are not easily predicted.

Given the evidence reviewed here, VO and VLO may support reward learning and performance over increasing delays (i.e., delay discounting), the learning of the variance of value distributions over time (i.e., learning of risk), and the conditions (context or state) in which outcomes are expected. All these functions likely support the stabilization of expectations necessary for appropriate behavioral responses to changing or surprising events. These are similar to the functions of MO, yet there is appreciably more emphasis on cue-guided learning in VO and VLO studies, a trend that continues as one moves more laterally through rat OFC. Critically, this may result from an overemphasis on the study of cue-outcome association learning, with few investigations probing the role of VO and VLO in cue-action and actionoutcome coding in mouse (compare Gremel and Costa, 2013).

\section{LO}

By far the most well explored area of OFC, investigated by a number of different groups, is LO. The Schoenbaum laboratory, in particular, has made significant progress in understanding the role of this region, as well as the role of LO-AI, which I define in the next section as a more lateral target than LO for convenience, to simplify comparisons and discussion. It should be noted, however, that LO and AI are frequently targeted in tandem (i.e., LO targets often also include AI). For the purpose of this Viewpoint, studies were classified as primarily LO studies on the basis of ML coordinates that extended more laterally than VLO, between \pm 2.5 to \pm 3.2 from the midline, at any AP level. If studies are clustered in this way (Table 4), it becomes clear that many inves- 
Table 4. Targeting of rat LO frontal cortex ${ }^{a}$

\begin{tabular}{|c|c|c|c|c|c|}
\hline Reference & Sex and strain & $\begin{array}{l}\text { OFC } \\
\text { target }\end{array}$ & Method & Behavioral task & Finding \\
\hline Fuchs et al., 2004 & Male, Sprague Dawley & $\mathrm{LO}$ & $\begin{array}{l}\text { NMDA lesions or baclofen/musci- } \\
\text { mol microinfusions }\end{array}$ & $\begin{array}{l}\text { Cue-induced and drug-primed reinstatement } \\
\text { of cocaine self-administration }\end{array}$ & $\begin{array}{l}\text { Impaired conditioned cue-induced } \\
\text { reinstatement; enhanced perseveration in } \\
\text { drug-primed condition }\end{array}$ \\
\hline $\begin{array}{l}\text { Kim and Ragozzino, } \\
2005\end{array}$ & Male, Long Evans & LO & Muscimol microinfusions & $\begin{array}{l}\text { Two- and four-choice discrimination and } \\
\text { reversal learning }\end{array}$ & $\begin{array}{l}\text { Intact discrimination learning, impaired two- } \\
\text { and four-choice reversal learning with } \\
\text { increased perseverative errors }\end{array}$ \\
\hline Kepecs et al., 2008 & Male, Long Evans & $\mathrm{LO}$ & Electrophysiological recording & $\begin{array}{l}\text { Postdecision confidence estimation in } \\
\text { willingness to wait }\end{array}$ & $\begin{array}{l}\text { Firing rates of single neurons match predictions } \\
\text { of confidence models }\end{array}$ \\
\hline $\begin{array}{l}\text { Takahashi et al., 2009; } \\
\text { Burke et al., } 2009\end{array}$ & Male, Long Evans & LO & Baclofen/muscimol microinfusions & $\begin{array}{l}\text { Pavlovian overexpectation; Pavlovian } \\
\text { learning }\end{array}$ & $\begin{array}{l}\text { Impaired learning from expected outcomes; } \\
\text { impaired reversal of Pavlovian responding }\end{array}$ \\
\hline Zeeb et al., 2010 & Male, Long Evans & LO & Baclofen/muscimol microinfusions & Cued and noncued delay discounting & $\begin{array}{l}\text { Increased impulsive choice when the delay was } \\
\text { cued; decreased impulsive choice when } \\
\text { delay was uncued }\end{array}$ \\
\hline Mar et al., 2011 & Male, Lister Hooded & $\mathrm{LO}$ & NMDA lesion & Delay discounting & $\begin{array}{l}\text { Increased preference for small immediate } \\
\text { rewards; attenuated reversal learning }\end{array}$ \\
\hline $\begin{array}{l}\text { Takahashi et al., 2013; } \\
\text { Lucantonio et al., } \\
2014\end{array}$ & Male, Long Evans & LO & $\begin{array}{l}\text { Electrophysiological recording and } \\
\text { optogenetic inhibition/activa- } \\
\text { tion }\end{array}$ & Pavlovian overexpectation & $\begin{array}{l}\text { Activity to cue-responsive neurons increases } \\
\text { with a compound cue and declines with } \\
\text { learning; a pattern abolished with prior } \\
\text { cocaine history }\end{array}$ \\
\hline Stott and Redish, 2014 & Male, Fisher Brown Norway & $\mathrm{LO}$ & Electrophysiological recording & Spatial-adjusting delay-discounting task & Reward-related signals occurred after choice \\
\hline Lak et al., 2014 & Male, Long Evans & LO & Muscimol microinfusions & $\begin{array}{l}\text { Postdecision confidence estimation in } \\
\text { willingness to wait }\end{array}$ & $\begin{array}{l}\text { Intact decision accuracy, disrupted waiting- } \\
\text { based confidence report }\end{array}$ \\
\hline $\begin{array}{l}\text { Moorman and Aston- } \\
\text { Jones, } 2014\end{array}$ & Male, Long Evans & $\mathrm{LO}$ & Electrophysiological recording & Context-based response inhibition & $\begin{array}{l}\text { Activity most robust to reward-predicting } \\
\text { stimuli; activity tracked reward when } \\
\text { contingencies reversed }\end{array}$ \\
\hline Lopatina et al., 2015 & Male, Long Evans & $\mathrm{LO}$ & Electrophysiological recording & Odor-based unblocking task & $\begin{array}{l}\text { Firing early in learning to valued cues } \\
\text { consistent with outcome features }\end{array}$ \\
\hline $\begin{array}{l}\text { Ramírez-Lugo et al., } \\
2016\end{array}$ & Male, Wistar & $\mathrm{LO}$ & Baclofen/muscimol microinfusions & Conditioned taste aversion choice/no choice & $\begin{array}{l}\text { Impaired choice behavior guided by learned } \\
\text { taste aversion, but not retrieval of taste } \\
\text { memory }\end{array}$ \\
\hline Dalton et al., 2016 & Male, Long Evans & LO & Baclofen/muscimol microinfusions & $\begin{array}{l}\text { Probabilistic discrimination and reversal } \\
\text { learning }\end{array}$ & $\begin{array}{l}\text { Intact discrimination learning, impaired } \\
\text { reversal learning }\end{array}$ \\
\hline Nogueira et al., 2017 & Male, Wister & $\mathrm{LO}$ & Electrophysiological recording & Auditory time-interval task & Signals choice before stimulus onset \\
\hline Amodeo et al., 2017 & Male, Sprague Dawley & LO & Electrophysiological recording & Probabilistic reversal learning & Signals reflect changes in contingencies \\
\hline
\end{tabular}

${ }^{a}$ Stereotaxic coordinates for L0: guide cannulae implanted AP 3.7, ML \pm 2.6, DV -4.7 (Ramírez-Lugo et al., 2016) or AP 3.8, ML \pm 2.6, DV -2.9 from dura (Zeeb et al., 2010). Tetrode recordings (Kepecs et al., 2008; Stott and Redish, 2014) at AP 3.5, ML \pm 2.5 , with similar coordinate recordings at AP 3.7, ML \pm 2.5 (Nogueira et al., 2017). Lesions at AP 3.2, ML $\pm 2.5, \mathrm{DV}-3.6$ (Fuchs et al., 2004; Mar et al., 2011). Inactivations at AP 3.8, ML \pm 2.6 , and DV - 3.2 from dura (Dalton et al., 2016). Inactivations slightly more anterolaterally at AP 4.0, ML \pm 3.2 , and DV -4 from dura (Kim and Ragozzino, 2005). More posterolateral inactivations at AP 3.0, ML \pm 3.2 , and DV -5.0 (Burke et al., 2009; Takahashi et al., 2009). Dual guide cannulae were implanted $1.5 \mathrm{~mm}$ above $\mathrm{L} 0$ at AP 4.1, ML $\pm 2.8, \mathrm{DV}-1.8$ from dura, and AP 3.2, ML $\pm 3.2, \mathrm{DV}-2.8$ from dura (Lak et al., 2014). Recording electrodes and optic fibers placed at AP 3.0, ML $\pm 3.2, \mathrm{DV}-4.2$ from brain surface (Takahashi et al., 2013; Lucantonio et al., 2014) and slightly more dorsally at -3.9 (Lopatina et al., 2015) and -4.0 (Amodeo et al., 2017). Electrodes placed at similar coordinates, although more ventrally, AP 3.2, ML \pm 3.2 , DV - 5.2 (Moorman and Aston-Jones, 2014).

tigations of LO have probed reversal learning, outcome prediction, and confidence estimates in rats. Many of these cognitive processes have been recently reviewed (Kepecs et al., 2008; Kepecs and Mainen, 2012; Rudebeck and Murray, 2014; Izquierdo et al., 2017), revealing a great deal of convergence between rat and monkey studies. In the rat, it has now been shown that LO is selectively involved in reversal learning (both deterministic and probabilistic), but not discrimination learning (Kim and Ragozzino, 2005; Dalton et al., 2016; Amodeo et al., 2017). Impaired reversal performance following LO inactivation also occurs in the context of Pavlovian responding (Burke et al., 2009), not just instrumental responding. LO also has a role in delay discounting: increasing preference for small, immediate over large, delayed rewards (Mar et al., 2011). As mentioned before, it was Zeeb et al. (2010) that made the important determination that the involvement of LO in delay discounting depends on whether there are explicit cues to signal delays to reward.

Highlighting the relevance of cues in LO function are addiction studies (Fanous et al., 2012). There are relatively few published reports of rat $\mathrm{LO}$ versus $\mathrm{MO}$ in studies involving drug reward (Fuchs et al., 2004; Lucantonio et al., 2014). One such finding was by Fuchs et al. (2004) showing that NMDA lesions of LO impaired cue-induced reinstatement of cocaine self-administration, whereas MO lesions left cue-induced reinstatement intact. Another group studied Pavlovian overexpectation, a task where outcomes (food rewards) may not be directly experienced during training but instead must be inferred or estimated when the rat is later exposed to a compound cue. Using this paradigm, it was determined that activity in cue-responsive neurons in LO increases initially with a compound cue and then declines with learning. Interestingly, this pattern is abolished in rats with a history of cocaine self-administration and is partnered with behavioral impairments that are rescued via optogenetic activation of LO (Lucantonio et al., 2014).

In many studies of LO function, cues are present in the task as prominent stimuli that enable the animal to predict outcomes. Some research groups focus their study of neural activity before and during cue onset (Moorman and Aston-Jones, 2014; Lopatina et al., 2015; Nogueira et al., 2017), whereas others are more interested in the signal after the rat selects a response (the "postdecision" epoch) (Kepecs et al., 2008; Lak et al., 2014; Stott and Redish, 2014). Overall, there is convincing evidence that LO sup- 
Table 5. Targeting of rat LO frontal cortex and AI cortex ${ }^{a}$

\begin{tabular}{|c|c|c|c|c|c|}
\hline Reference & Sex and strain & $\begin{array}{l}\text { OFC } \\
\text { target }\end{array}$ & Method & Behavioral task & Finding \\
\hline $\begin{array}{l}\text { Gallagher et al., 1999; } \\
\text { Pickens et al., 2003, } \\
2005\end{array}$ & Male, Long Evans & LO-Al & NMDA lesions & Reinforcer devaluation & $\begin{array}{l}\text { Impaired ability to associate cues with updated } \\
\text { value; difficulty maintaining representations }\end{array}$ \\
\hline $\begin{array}{l}\text { Schoenbaum et al., } \\
\text { 1999, 2000, } 2003\end{array}$ & Male, Long Evans & LO-Al & NMDA lesions & Odor discrimination and reversal learning & $\begin{array}{l}\text { Intact discrimination learning, impaired reversal } \\
\text { learning }\end{array}$ \\
\hline Bohn et al., 2003a,b & Male, Sprague Dawley & LO-Al & NMDA lesions & $\begin{array}{l}\text { Reaction time task with different } \\
\text { magnitude outcomes }\end{array}$ & $\begin{array}{l}\text { Intact discrimination, impaired stimulus-reward } \\
\text { magnitude reversal learning }\end{array}$ \\
\hline $\begin{array}{l}\text { Ostlund and Balleine, } \\
2007\end{array}$ & Female, Long Evans & LO-Al & NMDA lesions & $\begin{array}{l}\text { Instrumental outcome devaluation and } \\
\text { Pavlovian-instrumental transfer }\end{array}$ & $\begin{array}{l}\text { Intact instrumental outcome devaluation, } \\
\text { impaired Pavlovian-instrumental transfer }\end{array}$ \\
\hline McDannald et al., 2011 & Male, Long Evans & LO-Al & NMDA lesions & Odor-based unblocking & Impaired learning of reward identity \\
\hline McDannald et al., 2014 & Male, Long Evans & LO-Al & $\begin{array}{l}\text { Electrophysiological } \\
\text { recordings }\end{array}$ & Odor-based unblocking & $\begin{array}{l}\text { Firing to identity cues, independent of value } \\
\text { information }\end{array}$ \\
\hline $\begin{array}{l}\text { Riceberg and Shapiro, } \\
\quad 2012\end{array}$ & Male, Long Evans & LO-Al & NMDA lesions & $\begin{array}{l}\text { Spatial learning in a radial arm maze that } \\
\text { varied frequency of reversal }\end{array}$ & $\begin{array}{l}\text { Slower to learn low-frequency reversals but } \\
\text { quicker to learn high-frequency reversals }\end{array}$ \\
\hline Orsini et al., 2015 & Male, Long Evans & LO-Al & NMDA lesions & Punishment risk & $\begin{array}{l}\text { Intact discrimination of reward magnitude, } \\
\text { decreased risk-taking }\end{array}$ \\
\hline
\end{tabular}

${ }^{a}$ Stereotaxic coordinates for L0-Al: Site 1, AP 4.0, ML \pm 2.2 and \pm 3.7, DV -3.8 from skull surface; Site 2, AP 3.0, ML \pm 3.2 and \pm 4.2, DV -5.2 from skull surface (Gallagher et al., 1999; Schoenbaum et al., 1999, 2000; Pickens et al., 2003; Schoenbaum et al., 2003; Pickens et al., 2005; McDannald et al., 2011; Riceberg and Shapiro, 2012) for lesions. One group used a similar site for their lesions, AP 3.5, ML \pm 3.2 , DV -4.2 (Ostlund and Balleine, 2007), but more medially restricted. Electrodes were also implanted at a similar site, AP 3.0, ML \pm 3.2, DV -4.0 from skull surface (McDannald et al., 2014; Jo and Jung, 2016). A similar set of coordinates (Riceberg and Shapiro, 2012) was used by Bohn et al. (2003a, b) for lesions at identical AP and ML coordinates, but different DV ( -5.0 and -5.8 from skull surface). Another group administered lesions at AP 3.7, ML \pm 2.1 and $\pm 3.6, D V-4.4$ and -4.5, respectively; AP 3.0, ML \pm 2.6 and $\pm 3.9, D V$ -5.2 and -5.0 , respectively (Orsini et al., 2015).

ports cue-based outcome prediction as well as decision confidence estimates in rats, as measured by rats' willingness to wait for reward.

Given the evidence that $\mathrm{MO}$ and $\mathrm{VO}$ project rather sparsely to LO compared with other cortical regions (Hoover and Vertes, 2011), LO may rely less on these corticocortical motivational or affective state signals and more on inputs directly from piriform cortex, rhinal cortex, and basolateral amygdala conveying sensory features about cues that predict specific outcomes. This could support high-resolution cue-based outcome predictions.

\section{LO-AI}

More lateral LO-AI is also well explored and features much converging evidence. Designation of LO-AI was determined on the basis of the most lateral ML coordinates in rat OFC: between \pm 3.2 to \pm 4.2 from the midline, at any AP level of OFC, although targeting of this subregion is generally more caudal. Several studies have probed ventral and dorsal AI in addition to LO (Table 5), which collectively receive dense projections from piriform cortex and basolateral amygdala (Price, 2007; Wassum and Izquierdo, 2015). NMDA lesions more restricted to LO-AI have resulted in intact discrimination learning but impaired reversal learning (Schoenbaum et al., 1999, 2000, 2003; Bohn et al., 2003a, b). Additionally, LO lesions do not produce impairments in the ability to discriminate between different reward magnitudes (Bohn et al., 2003a; Orsini et al., 2015). More recent studies have refined the role of LO and LO-AI to support reversal learning only under particular conditions, specifically in low-frequency reversals (Riceberg and Shapiro, 2012). For example, if rats have fewer experiences with switching reward contingencies, OFC lesions impair reversal learning and lead to more perseverative errors; but if rats already have many more experiences with reversals beforehand, OFC lesions actually improve performance. This suggests that the most lateral sectors of OFC are important in (1) keeping track of reward statistics and/or (2) stabilizing the reward distribution to represent the average outcome. Both possibilities would be important in updating behavior in changing environments. There are several similarities here with findings in $\mathrm{VO}$ and VLO. When recording from VLO, Riceberg and Shapiro (2017) found evidence that OFC does indeed maintain a record of reward history: signaling in VLO was predictive of future behavior only if the reward statistics were stable.

Another function of LO-AI is in adaptive responses to reinforcer devaluation, when rats are assessed after selective satiation with a particular reward. Lesions to this region impair the ability to associate cues with an updated value (Gallagher et al., 1999; Pickens et al., 2003; Pickens et al., 2005; Ostlund and Balleine, 2007). More recent investigations of this region have probed Pavlovian unblocking (McDannald et al., 2011, 2014). In this procedure, rats are trained to associate different cues with either an increase in reward magnitude (a change in both reward identity and value) or a change in the flavor of the reward (change in reward identity without a change in value, confirmed by behavioral test). The cues are then presented in compound with novel cues where the reward magnitude or identity is changed. Unblocking was assessed by presenting the cues alone in a probe test. It was determined that some LO neurons acquire responses to cues predicting both value and "valueless" (simple reward identity) changes. This is support that rat LO/LO-AI is involved in signaling expected outcomes based on sensory and/or perceptual features, even apart from their value.

How do the roles of these more lateral sectors of OFC in responses to reinforcer devaluation and in reversal learning fit with the proposed roles for MO and VO/VLO described earlier? To respond appropriately to both changes in value and changes in contingencies, one would need access to value representations and stable expectations acquired through experience. So even if $\mathrm{MO}$ and VO projections to LO are relatively sparse compared with other cortical regions, this information appears to be important to LO function. Another intriguing possibility is that the functions of MO and VO are redundant to LO (considered in more detail below).

In summary for LO-AI, there may be little functional difference between LO and more laterally targeted LO-AI in reward learning and decision making in the rat, although there is still a need to distinguish the role of LO from AI in appetitive behavior. 


\section{Future directions in rat OFC}

What remains to be studied in rat OFC? As shown in Figure 3, reversal learning effects have been reported following targeting of most sectors of OFC, in various laboratories, and across sensory modalities. Of the variants used, deterministic, fully predictive reversal learning tasks have been administered following manipulations and recordings in much of rat OFC (for review, see Izquierdo et al., 2017), with many fewer assessments of probabilistic reversal learning (Dalton et al., 2016). Indeed, many of the studies discussed here assessed well-trained rats for their performance after extensive experience on task. More experiments assessing OFC function in rats while learning about uncued or unobservable outcomes would be welcome. Similarly, there appears to be a shortage of investigations of responses to devaluation in rat $\mathrm{VO}$ and $\mathrm{LO}$, confidence estimates in rat $\mathrm{MO}$, reward magnitude and reward identity discrimination in $\mathrm{MO}$ and $\mathrm{VO}$, and strategy/set shifting and delay discounting in rat LO. Importantly, as shown in Tables 1-5, almost all of the experiments included in this Viewpoint have been conducted in male, pigmented strains (mostly in Long-Evans), with very few female rat subjects. This may change with a new awareness that female rats are not more variable than males and should be included in future research (Becker et al., 2016).

Moving forward, the biggest concern for the future of rat OFC is the influence of confirmation bias because there are, at present, many theoretical viewpoints driving the empirical work, with increasingly sophisticated computational models fit to behavior. Additionally, as described earlier, there is an oversampling of certain subregions for study, which I have attempted to highlight. Greater exploration should be conducted in MO and VO, and knowledge of rat neuroanatomy should remain at the center of future experimental design and inquiry.

Related to the point above, a decade ago, Price (2007) expressed a need for the systematic study of corticocortical connections in rat OFC. At present, these corticocortical connections still remain to be more comprehensively investigated, although there has been progress (Hoover and Vertes, 2011). Several neuroanatomists have now proposed that $\mathrm{MO}$ and $\mathrm{VO}$ may function as a bridge between LO and the medial wall of the PFC (mPFC) (Price, 2007; Hoover and Vertes, 2011; Heilbronner et al., 2016). The behavioral evidence summarized here also supports the idea that $\mathrm{MO}$ is most linked to motivational states, with best access to areas coding incentive value, such as the nucleus accumbens. As such, MO and perhaps also VO have better access to values that are in flux or outcomes that are uncertain, as in the salience of early learning or in rapidly changing, volatile environments. One possibility mentioned above is that the functions of $\mathrm{MO}$ and $\mathrm{VO}$ are redundant to LO. This is an interesting possibility in light of the idea that cortical representations are hierarchical and recurrent in supporting reward choices: value computations are emergent properties that take shape across time and across cortical regions (Hunt and Hayden, 2017), with no real functional localization or modules per se. Alhough derived largely from studies of human and nonhuman primate cortex, moving forward, exploration of rat OFC could benefit from this refreshing perspective to generate testable hypotheses.

Also required for the future is a more direct comparison of LO and AI. Importantly, some groups have initiated the much-needed investigation of the distinction between $\mathrm{LO}$ and $\mathrm{AI}$ in appetitive behavior (Jean-Richard-Dit-Bressel and McNally, 2016; Jo and Jung, 2016; Parkes et al., 2017). Finally, although the list is growing quickly (Lichtenberg et al., 2017; Wikenheiser et al., 2017), there are far fewer cell-specific circuit dissection techniques directed at rat OFC compared with more traditional approaches. These newer technologies would ideally be leveraged with concurrent assessment of sophisticated rat behavior.

\section{References}

Akaishi R, Kolling N, Brown JW, Rushworth M (2016) Neural mechanisms of credit assignment in a multicue environment. J Neurosci 36:10961112. CrossRef Medline

Amodeo LR, McMurray MS, Roitman JD (2017) Orbitofrontal cortex reflects changes in response-outcome contingencies during probabilistic reversal learning. Neuroscience 345:27-37. CrossRef Medline

Bakhurin KI, Goudar V, Shobe JL, Claar LD, Buonomano DV, Masmanidis SC (2017) Differential encoding of time by prefrontal and striatal network dynamics. J Neurosci 37:854-870. CrossRef Medline

Becker JB, Prendergast BJ, Liang JW (2016) Female rats are not more variable than male rats: a meta-analysis of neuroscience studies. Biol Sex Differ 7:34. CrossRef Medline

Bissonette GB, Martins GJ, Franz TM, Harper ES, Schoenbaum G, Powell EM (2008) Double dissociation of the effects of medial and orbital prefrontal cortical lesions on attentional and affective shifts in mice. J Neurosci 28:11124-11130. CrossRef Medline

Bissonette GB, Schoenbaum G, Roesch MR, Powell EM (2015) Interneurons are necessary for coordinated activity during reversal learning in orbitofrontal cortex. Biol Psychiatry 77:454-464. CrossRef Medline

Bohn I, Giertler C, Hauber W (2003a) Orbital prefrontal cortex and guidance of instrumental behavior of rats by visuospatial stimuli predicting reward magnitude. Learn Mem 10: 177-186. CrossRef Medline

Bohn I, Giertler C, Hauber W (2003b) Orbital prefrontal cortex and guidance of instrumental behaviour in rats under reversal conditions. Behav Brain Res 143:49-56. CrossRef Medline

Boulougouris V, Dalley JW, Robbins TW (2007) Effects of orbitofrontal, infralimbic and prelimbic cortical lesions on serial spatial reversal learning in the rat. Behav Brain Res 179:219-228. CrossRef Medline

Bradfield LA, Dezfouli A, van Holstein M, Chieng B, Balleine BW (2015) Medial orbitofrontal cortex mediates outcome retrieval in partially observable task situations. Neuron 88:1268-1280. CrossRef Medline

Brigman JL, Daut RA, Wright T, Gunduz-Cinar O, Graybeal C, Davis MI, Jiang Z, Saksida LM, Jinde S, Pease M, Bussey TJ, Lovinger DM, Nakazawa K, Holmes A (2013) GluN2B in corticostriatal circuits governs choice learning and choice shifting. Nat Neurosci 16:1101-1110. CrossRef Medline

Bryden DW, Roesch MR (2015) Executive control signals in orbitofrontal cortex during response inhibition. J Neurosci 35:3903-3914. CrossRef Medline

Burguière E, Monteiro P, Feng G, Graybiel AM (2013) Optogenetic stimulation of lateral orbitofronto-striatal pathway suppresses compulsive behaviors. Science 340:1243-1246. CrossRef Medline

Burke KA, Takahashi YK, Correll J, Brown PL, Schoenbaum G (2009) Orbitofrontal inactivation impairs reversal of Pavlovian learning by interfering with 'disinhibition' of responding for previously unrewarded cues. Eur J Neurosci 30:1941-1946. CrossRef Medline

Burton AC, Kashtelyan V, Bryden DW, Roesch MR (2014) Increased firing to cues that predict low-value reward in the medial orbitofrontal cortex. Cereb Cortex 24:3310-3321. CrossRef Medline

Butter CM, Mishkin M, Rosvold HE (1963) Conditioning and extinction of a food-rewarded response after selective ablations of frontal cortex in rhesus monkeys. Exp Neurol 7:65-75. CrossRef Medline

Camille N, Coricelli G, Sallet J, Pradat-Diehl P, Duhamel JR, Sirigu A (2004) The involvement of the orbitofrontal cortex in the experience of regret. Science 304:1167-1170. CrossRef Medline

Chase EA, Tait DS, Brown VJ (2012) Lesions of the orbital prefrontal cortex impair the formation of attentional set in rats. Eur J Neurosci 36:23682375. CrossRef Medline

Chau BK, Sallet J, Papageorgiou GK, Noonan MP, Bell AH, Walton ME, Rushworth MF (2015) Contrasting roles for orbitofrontal cortex and amygdala in credit assignment and learning in macaques. Neuron 87: 1106-1118. CrossRef Medline

Chudasama Y, Robbins TW (2003) Dissociable contributions of the orbitofrontal and infralimbic cortex to pavlovian autoshaping and discrimination reversal learning: further evidence for the functional heterogeneity of the rodent frontal cortex. J Neurosci 23:8771-8780. Medline

Chudasama Y, Passetti F, Rhodes SE, Lopian D, Desai A, Robbins TW (2003) Dissociable aspects of performance on the 5-choice serial reaction time 
task following lesions of the dorsal anterior cingulate, infralimbic and orbitofrontal cortex in the rat: differential effects on selectivity, impulsivity and compulsivity. Behav Brain Res 146:105-119. CrossRef Medline

Dalton GL, Wang NY, Phillips AG, Floresco SB (2016) Multifaceted contributions by different regions of the orbitofrontal and medial prefrontal cortex to probabilistic reversal learning. J Neurosci 36:1996-2006. CrossRef Medline

de Carvalho LP, Bochet P, Rossier J (1996) The endogenous agonist quinolinic acid and the nonendogenous homoquinolinic acid discriminate between NMDAR2 receptor subunits. Neurochem Int 28:445-452. CrossRef Medline

Eagle DM, Baunez C, Hutcheson DM, Lehmann O, Shah AP, Robbins TW (2008) Stop-signal reaction-time task performance: role of prefrontal cortex and subthalamic nucleus. Cereb Cortex 18:178-188. CrossRef Medline

Fanous S, Goldart EM, Theberge FR, Bossert JM, Shaham Y, Hope BT (2012) Role of orbitofrontal cortex neuronal ensembles in the expression of incubation of heroin craving. J Neurosci 32:11600-11609. CrossRef Medline

Fuchs RA, Evans KA, Parker MP, See RE (2004) Differential involvement of orbitofrontal cortex subregions in conditioned cue-induced and cocaineprimed reinstatement of cocaine seeking in rats. J Neurosci 24:66006610. CrossRef Medline

Gallagher M, McMahan RW, Schoenbaum G (1999) Orbitofrontal cortex and representation of incentive value in associative learning. J Neurosci 19:6610-6614. Medline

Goldman PS (1971) Functional development of the prefrontal cortex in early life and the problem of neuronal plasticity. Exp Neurol 32:366-387. CrossRef Medline

Gourley SL, Taylor JR (2016) Going and stopping: dichotomies in behavioral control by the prefrontal cortex. Nat Neurosci 19:656-664. CrossRef Medline

Gourley SL, Olevska A, Zimmermann KS, Ressler KJ, Dileone RJ, Taylor JR (2013) The orbitofrontal cortex regulates outcome-based decisionmaking via the lateral striatum. Eur J Neurosci 38:2382-2388. CrossRef Medline

Gourley SL, Zimmermann KS, Allen AG, Taylor JR (2016) The medial orbitofrontal cortex regulates sensitivity to outcome value. J Neurosci 36: 4600-4613. CrossRef Medline

Gremel CM, Costa RM (2013) Orbitofrontal and striatal circuits dynamically encode the shift between goal-directed and habitual actions. Nat Commun 4:2264. CrossRef Medline

Groenewegen HJ (1988) Organization of the afferent connections of the mediodorsal thalamic nucleus in the rat, related to the mediodorsalprefrontal topography. Neuroscience 24:379-431. CrossRef Medline

Hamilton DA, Brigman JL (2015) Behavioral flexibility in rats and mice: contributions of distinct frontocortical regions. Genes Brain Behav 14:421. CrossRef Medline

Hardung S, Epple R, Jäckel Z, Eriksson D, Uran C, Senn V, Gibor L, Yizhar O, Diester I (2017) A functional gradient in the rodent prefrontal cortex supports behavioral inhibition. Curr Biol 27:549-555. CrossRef Medline

Heilbronner SR, Rodriguez-Romaguera J, Quirk GJ, Groenewegen HJ, Haber SN (2016) Circuit-based corticostriatal homologies between rat and primate. Biol Psychiatry 80:509-521. CrossRef Medline

Hoover WB, Vertes RP (2011) Projections of the medial orbital and ventral orbital cortex in the rat. J Comp Neurol 519:3766-3801. CrossRef Medline

Hunt LT, Hayden BY (2017) A distributed, hierarchical and recurrent framework for reward-based choice. Nat Rev Neurosci 18:172-182. CrossRef Medline

Izquierdo A, Darling C, Manos N, Pozos H, Kim C, Ostrander S, Cazares V, Stepp H, Rudebeck PH (2013) Basolateral amygdala lesions facilitate reward choices after negative feedback in rats. J Neurosci 33:4105-4109. CrossRef Medline

Izquierdo A, Brigman JL, Radke AK, Rudebeck PH, Holmes A (2017) The neural basis of reversal learning: an updated perspective. Neuroscience 345:12-26. CrossRef Medline

Jang AI, Costa VD, Rudebeck PH, Chudasama Y, Murray EA, Averbeck BB (2015) The role of frontal cortical and medial-temporal lobe brain areas in learning a Bayesian prior belief on reversals. J Neurosci 35:1175111760. CrossRef Medline

Jean-Richard-Dit-Bressel P, McNally GP (2016) Lateral, not medial, prefrontal cortex contributes to punishment and aversive instrumental learning. Learn Mem 23:607-617. CrossRef Medline
Jentsch JD, Ashenhurst JR, Cervantes MC, Groman SM, James AS, Pennington ZT (2014) Dissecting impulsivity and its relationships to drug addictions. Ann N Y Acad Sci 1327:1-26. CrossRef Medline

Jo S, Jung MW (2016) Differential coding of uncertain reward in rat insular and orbitofrontal cortex. Sci Rep 6:24085. CrossRef Medline

Jones B, Mishkin M (1972) Limbic lesions and the problem of stimulusreinforcement associations. Exp Neurol 36:362-377. CrossRef Medline

Kepecs A, Mainen ZF (2012) A computational framework for the study of confidence in humans and animals. Philos Trans R Soc Lond B Biol Sci 367:1322-1337. CrossRef Medline

Kepecs A, Uchida N, Zariwala HA, Mainen ZF (2008) Neural correlates, computation and behavioural impact of decision confidence. Nature 455: 227-231. CrossRef Medline

Kheramin S, Body S, Mobini S, Ho MY, Velazquez-Martinez DN, Bradshaw CM, Szabadi E, Deakin JF, Anderson IM (2002) Effects of quinolinic acid-induced lesions of the orbital prefrontal cortex on inter-temporal choice: a quantitative analysis. Psychopharmacology (Berl) 165:9-17. CrossRef Medline

Kheramin S, Body S, Ho M, Velázquez-Martinez DN, Bradshaw CM, Szabadi E, Deakin JF, Anderson IM (2003) Role of the orbital prefrontal cortex in choice between delayed and uncertain reinforcers: a quantitative analysis. Behav Processes 64:239-250. CrossRef Medline

Kheramin S, Body S, Herrera FM, Bradshaw CM, Szabadi E, Deakin JF, Anderson IM (2005) The effect of orbital prefrontal cortex lesions on performance on a progressive ratio schedule: implications for models of inter-temporal choice. Behav Brain Res 156:145-152. CrossRef Medline

Kim J, Ragozzino ME (2005) The involvement of the orbitofrontal cortex in learning under changing task contingencies. Neurobiol Learn Mem 83: 125-133. CrossRef Medline

Kolb B (1984) Functions of the frontal cortex of the rat: a comparative review. Brain Res 320:65-98. Medline

Lak A, Costa GM, Romberg E, Koulakov AA, Mainen ZF, Kepecs A (2014) Orbitofrontal cortex is required for optimal waiting based on decision confidence. Neuron 84:190-201. CrossRef Medline

Lichtenberg NT, Pennington ZT, Holley SM, Greenfield VY, Cepeda C, Levine MS, Wassum KM (2017) Basolateral amygdala to orbitofrontal cortex projections enable cue-triggered reward expectations. J Neurosci 37:8374-8384. Medline

Lopatina N, McDannald MA, Styer CV, Sadacca BF, Cheer JF, Schoenbaum G (2015) Lateral orbitofrontal neurons acquire responses to upshifted, downshifted, or blocked cues during unblocking. Elife 4:e11299. CrossRef Medline

Lopatina N, McDannald MA, Styer CV, Peterson JF, Sadacca BF, Cheer JF, Schoenbaum G (2016) Medial orbitofrontal neurons preferentially signal cues predicting changes in reward during unblocking. J Neurosci 36:8416-8424. CrossRef Medline

Lopatina N, Sadacca BF, McDannald MA, Styer CV, Peterson JF, Cheer JF, Schoenbaum G (2017) Ensembles in medial and lateral orbitofrontal cortex construct cognitive maps emphasizing different features of the behavioral landscape. Behav Neurosci 131:201-212. CrossRef Medline

Lucantonio F, Takahashi YK, Hoffman AF, Chang CY, Bali-Chaudhary S, Shaham Y, Lupica CR, Schoenbaum G (2014) Orbitofrontal activation restores insight lost after cocaine use. Nat Neurosci 17:1092-1099. CrossRef Medline

Lucantonio F, Gardner MP, Mirenzi A, Newman LE, Takahashi YK, Schoenbaum G (2015) Neural estimates of imagined outcomes in basolateral amygdala depend on orbitofrontal cortex. J Neurosci 35:16521-16530. CrossRef Medline

Lugo-Huitrón R, Ugalde Muñiz P, Pineda B, Pedraza-Chaverrí J, Ríos C, Pérez-de la Cruz V (2013) Quinolinic acid: an endogenous neurotoxin with multiple targets. Oxid Med Cell Longev 2013:104024. CrossRef Medline

Mansouri FA, Buckley MJ, Tanaka K (2014) The essential role of primate orbitofrontal cortex in conflict-induced executive control adjustment. J Neurosci 34:11016-11031. CrossRef Medline

Mar AC, Walker AL, Theobald DE, Eagle DM, Robbins TW (2011) Dissociable effects of lesions to orbitofrontal cortex subregions on impulsive choice in the rat. J Neurosci 31:6398-6404. CrossRef Medline

Markowitsch HJ, Pritzel M (1979) Prefrontal cortex: projection area of the thalamic mediodorsal nucleus. Physiol Psychol 7:1-6. CrossRef

McAlonan K, Brown VJ (2003) Orbital prefrontal cortex mediates reversal 
learning and not attentional set shifting in the rat. Behav Brain Res 146: 97-103. CrossRef Medline

McDannald MA, Lucantonio F, Burke KA, Niv Y, Schoenbaum G (2011) Ventral striatum and orbitofrontal cortex are both required for modelbased, but not model-free, reinforcement learning. J Neurosci 31:27002705. CrossRef Medline

McDannald MA, Esber GR, Wegener MA, Wied HM, Liu TL, Stalnaker TA, Jones JL, Trageser J, Schoenbaum G (2014) Orbitofrontal neurons acquire responses to 'valueless' Pavlovian cues during unblocking. Elife 3:e02653. CrossRef Medline

Meyer HC, Bucci DJ (2016) Imbalanced activity in the orbitofrontal cortex and nucleus accumbens impairs behavioral inhibition. Curr Biol 26: 2834-2839. CrossRef Medline

Mobini S, Body S, Ho MY, Bradshaw CM, Szabadi E, Deakin JF, Anderson IM (2002) Effects of lesions of the orbitofrontal cortex on sensitivity to delayed and probabilistic reinforcement. Psychopharmacology (Berl) 160: 290-298. CrossRef Medline

Moorman DE, Aston-Jones G (2014) Orbitofrontal cortical neurons encode expectation-driven initiation of reward-seeking. J Neurosci 34:1023410246. CrossRef Medline

Nogueira R, Abolafia JM, Drugowitsch J, Balaguer-Ballester E, Sanchez-Vives MV, Moreno-Bote R (2017) Lateral orbitofrontal cortex anticipates choices and integrates prior with current information. Nat Commun 8:14823. CrossRef Medline

Noonan MP, Kolling N, Walton ME, Rushworth MF (2012) Re-evaluating the role of the orbitofrontal cortex in reward and reinforcement. Eur J Neurosci 35:997-1010. CrossRef Medline

Noonan MP, Chau BK, Rushworth MF, Fellows LK (2017) Contrasting effects of medial and lateral orbitofrontal cortex lesions on credit assignment and decision making in humans. J Neurosci 37:7023-7035. CrossRef Medline

Ongür D, Price JL (2000) The organization of networks within the orbital and medial prefrontal cortex of rats, monkeys and humans. Cereb Cortex 10:206-219. CrossRef Medline

Orsini CA, Trotta RT, Bizon JL, Setlow B (2015) Dissociable roles for the basolateral amygdala and orbitofrontal cortex in decision-making under risk of punishment. J Neurosci 35:1368-1379. CrossRef Medline

Ostlund SB, Balleine BW (2007) Orbitofrontal cortex mediates outcome encoding in Pavlovian but not instrumental conditioning. J Neurosci 27:4819-4825. CrossRef Medline

Ostrander S, Cazares VA, Kim C, Cheung S, Gonzalez I, Izquierdo A (2011) Orbitofrontal cortex and basolateral amygdala lesions result in suboptimal and dissociable reward choices on cue-guided effort in rats. Behav Neurosci 125:350-359. CrossRef Medline

Otchy TM, Wolff SB, Rhee JY, Pehlevan C, Kawai R, Kempf A, Gobes SM, Ölveczky BP (2015) Acute off-target effects of neural circuit manipulations. Nature 528:358-363. CrossRef Medline

Padoa-Schioppa C, Assad JA (2006) Neurons in the orbitofrontal cortex encode economic value. Nature 441:223-226. CrossRef Medline

Parkes SL, Ravassard PM, Cerpa JC, Wolff M, Ferreira G, Coutureau E (2017) Insular and ventrolateral orbitofrontal cortices differentially contribute to goal-directed behavior in rodents. Cereb Cortex. Advance online publication. Retrieved May 25, 2017. doi: 10.1093/cercor/bhx132. CrossRef Medline

Passingham RE, Wise SP (2012) The neurobiology of the prefrontal cortex: anatomy, evolution, and the origin of insight. Oxford: Oxford UP.

Paxinos G, Watson C (2007) The rat brain in stereotaxic coordinates, Ed 6. Burlington, MA: Academic.

Pickens CL, Saddoris MP, Setlow B, Gallagher M, Holland PC, Schoenbaum G (2003) Different roles for orbitofrontal cortex and basolateral amygdala in a reinforcer devaluation task. J Neurosci 23:11078-11084. Medline

Pickens CL, Saddoris MP, Gallagher M, Holland PC (2005) Orbitofrontal lesions impair use of cue-outcome associations in a devaluation task. Behav Neurosci 119:317-322. CrossRef Medline

Price JL (2007) Definition of the orbital cortex in relation to specific connections with limbic and visceral structures and other cortical regions. Ann N Y Acad Sci 1121:54-71. CrossRef Medline

Radke AK, Jury NJ, Kocharian A, Marcinkiewcz CA, Lowery-Gionta EG, Pleil KE, McElligott ZA, McKlveen JM, Kash TL, Holmes A (2017) Chronic EtOH effects on putative measures of compulsive behavior in mice. Addict Biol 22:423-434. CrossRef Medline

Ramírez-Lugo L, Peñas-Rincón A, Ángeles-Durán S, Sotres-Bayon F (2016)
Choice behavior guided by learned, but not innate, taste aversion recruits the orbitofrontal cortex. J Neurosci 36:10574-10583. CrossRef Medline

Ray JP, Price JL (1992) The organization of the thalamocortical connections of the mediodorsal thalamic nucleus in the rat, related to the ventral forebrain-prefrontal cortex topography. J Comp Neurol 323:167-197. CrossRef Medline

Rempel-Clower NL (2007) Role of orbitofrontal cortex connections in emotion. Ann N Y Acad Sci 1121:72-86. CrossRef Medline

Riceberg JS, Shapiro ML (2012) Reward stability determines the contribution of orbitofrontal cortex to adaptive behavior. J Neurosci 32:1640216409. CrossRef Medline

Riceberg JS, Shapiro ML (2017) Orbitofrontal cortex signals expected outcomes with predictive codes when stable contingencies promote the integration of reward history. J Neurosci 37:2010-2021. CrossRef Medline

Rose JE, Woolsey CN (1948) The orbitofrontal cortex and its connections with the mediodorsal nucleus in rabbit, sheep and cat. Res Publ Assoc Res Nerv Ment Dis 27:210-232. Medline

Rudebeck PH, Murray EA (2014) The orbitofrontal oracle: cortical mechanisms for the prediction and evaluation of specific behavioral outcomes. Neuron 84:1143-1156. CrossRef Medline

Rudebeck PH, Walton ME, Smyth AN, Bannerman DM, Rushworth MF (2006) Separate neural pathways process different decision costs. Nat Neurosci 9:1161-1168. CrossRef Medline

Rudebeck PH, Walton ME, Millette BH, Shirley E, Rushworth MF, Bannerman DM (2007) Distinct contributions of frontal areas to emotion and social behaviour in the rat. Eur J Neurosci 26:2315-2326. CrossRef Medline

Schoenbaum G, Chiba AA, Gallagher M (1999) Neural encoding in orbitofrontal cortex and basolateral amygdala during olfactory discrimination learning. J Neurosci 19:1876-1884. Medline

Schoenbaum G, Chiba AA, Gallagher M (2000) Changes in functional connectivity in orbitofrontal cortex and basolateral amygdala during learning and reversal training. J Neurosci 20:5179-5189. Medline

Schoenbaum G, Setlow B, Nugent SL, Saddoris MP, Gallagher M (2003) Lesions of orbitofrontal cortex and basolateral amygdala complex disrupt acquisition of odor-guided discriminations and reversals. Learn Mem 10:129-140. CrossRef Medline

Schuck NW, Cai MB, Wilson RC, Niv Y (2016) Human orbitofrontal cortex represents a cognitive map of state space. Neuron 91:1402-1412. CrossRef Medline

Stalnaker TA, Cooch NK, Schoenbaum G (2015) What the orbitofrontal cortex does not do. Nat Neurosci 18:620-627. CrossRef Medline

Steiner AP, Redish AD (2012) The road not taken: neural correlates of decision making in orbitofrontal cortex. Front Neurosci 6:131. Medline

Steiner AP, Redish AD (2014) Behavioral and neurophysiological correlates of regret in rat decision-making on a neuroeconomic task. Nat Neurosci 17:995-1002. CrossRef Medline

Stolyarova A, Izquierdo A (2017) Complementary contributions of basolateral amygdala and orbitofrontal cortex to value learning under uncertainty. Elife 6:e27483. CrossRef Medline

Stopper CM, Green EB, Floresco SB (2014) Selective involvement by the medial orbitofrontal cortex in biasing risky, but not impulsive, choice. Cereb Cortex 24:154-162. CrossRef Medline

Stott JJ, Redish AD (2014) A functional difference in information processing between orbitofrontal cortex and ventral striatum during decisionmaking behaviour. Philos Trans R Soc Lond B Biol Sci 369:20130472. CrossRef Medline

Tait DS, Brown VJ (2007) Difficulty overcoming learned non-reward during reversal learning in rats with ibotenic acid lesions of orbital prefrontal cortex. Ann N Y Acad Sci 1121:407-420. CrossRef Medline

Takahashi YK, Roesch MR, Stalnaker TA, Haney RZ, Calu DJ, Taylor AR, Burke KA, Schoenbaum G (2009) The orbitofrontal cortex and ventral tegmental area are necessary for learning from unexpected outcomes. Neuron 62:269-280. CrossRef Medline

Takahashi YK, Chang CY, Lucantonio F, Haney RZ, Berg BA, Yau HJ, Bonci A, Schoenbaum G (2013) Neural estimates of imagined outcomes in the orbitofrontal cortex drive behavior and learning. Neuron 80:507-518. CrossRef Medline

Torregrossa MM, Quinn JJ, Taylor JR (2008) Impulsivity, compulsivity, and habit: the role of orbitofrontal cortex revisited. Biol Psychiatry 63:253255. CrossRef Medline

Tremblay L, Schultz W (1999) Relative reward preference in primate orbitofrontal cortex. Nature 398:704-708. CrossRef Medline 
Tremblay L, Schultz W (2000) Modifications of reward expectation-related neuronal activity during learning in primate orbitofrontal cortex. J Neurophysiol 83:1877-1885. Medline

Uylings HB, van Eden CG (1990) Qualitative and quantitative comparison of the prefrontal cortex in rat and in primates, including humans. Prog Brain Res 85:31-62. Medline

Wallis JD (2011) Cross-species studies of orbitofrontal cortex and valuebased decision-making. Nat Neurosci 15:13-19. CrossRef Medline

Walton ME, Behrens TE, Noonan MP, Rushworth MF (2011) Giving credit where credit is due: orbitofrontal cortex and valuation in an uncertain world. Ann N Y Acad Sci 1239:14-24. CrossRef Medline

Wassum KM, Izquierdo A (2015) The basolateral amygdala in reward learning and addiction. Neurosci Biobehav Rev 57:271-283. CrossRef Medline
Wikenheiser AM, Marrero-Garcia Y, Schoenbaum G (2017) Suppression of ventral hippocampal output impairs integrated orbitofrontal encoding of task structure. Neuron 95:1197-1207.e3. CrossRef Medline

Wilson RC, Takahashi YK, Schoenbaum G, Niv Y (2014) Orbitofrontal cortex as a cognitive map of task space. Neuron 81:267-279. CrossRef Medline

Winstanley CA, Theobald DE, Cardinal RN, Robbins TW (2004) Contrasting roles of basolateral amygdala and orbitofrontal cortex in impulsive choice. J Neurosci 24:4718-4722. CrossRef Medline

Young JJ, Shapiro ML (2011) Dynamic coding of goal-directed paths by orbital prefrontal cortex. J Neurosci 31:5989-6000. CrossRef Medline

Zeeb FD, Floresco SB, Winstanley CA (2010) Contributions of the orbitofrontal cortex to impulsive choice: interactions with basal levels of impulsivity, dopamine signalling, and reward-related cues. Psychopharmacology (Berl) 211:87-98. CrossRef Medline 